\title{
Approach to Innovations in Rural Communes
}

\author{
Joanna STEFANCZYK, Barbara GOLEBIEWSKA \\ Warsaw University of Life Sciences, Warsaw, Poland \\ \{joanna_stefanczyk,barbara_golebiewska\}@sggw.pl
}

\begin{abstract}
The aim of the article is to discuss the implementation of innovation in rural areas. Rural areas are perceived as less innovative than urbanized areas. This also applies to agriculture. In addition, there is a large diversity of development and implementation of innovation in agricultural activity. The research was conducted on the example of 30 farms located in rural Warmia Mazury. The agriculture of the Warmian-Masurian Voivodship requires a high level of technical utilities and cause that unit costs of agricultural production are higher, while profitability is lower than in other regions of the country. Direct interviews were conducted to obtain accurate information. The original interview questionnaire contained 9 questions concerning mainly introduced innovations, reasons for not undertaking innovative activities and respondents' opinions on the benefits of such activities. The information obtained and the results of analyzes allowed to indicate the main types of innovative activities implemented in selected areas. However, the scope of activities was limited. Farmers were not convinced to introduce such activities in their own farms and expected support from the state or EU funds. All respondents were unanimous that Poland's entry into EU structures gave Polish agriculture a great chance to improve farms situation. The research results also indicate that providing farmers better access to knowledge in the field of innovation can raise the innovation rate in the area of agricultural activity. In addition, respondents would like the commune authorities to work on improving the region's competitiveness and social inclusion.
\end{abstract}

Keywords: Innovations, Agriculture, Rural Areas.

\section{$1 \quad$ Introduction}

Contemporary Polish economy to be able to compete with the economies of such countries as Germany or France must place a special emphasis on research and development, science and, above all, the resulting innovations for implementation by native enterprises. Especially that innovations are a priority of the European Union's socio-economic development program, which is confirmed by the creation of the Innovation Union. The Community, through a range of tools, encourages Member States to invest in research and development at three percent of their GDP by 2020 [5]. At present, the areas of special interest of the Union are: food security, energy, aging of societies and climate change, therefore the implementation of innovations especially 
in these aspects of the Community's functioning is a priority. Unfortunately, according to the European Innovation Ranking 2018, Poland and most of the New EU countries occupy the last places in terms of innovation implementation. In this respect, the cause may be social unwillingness resulting, for example, from a lack of education in this area. The way to solve this is cooperation, innovation is no longer regarded as an individual but as a network process [10]. One example is the "Cooperation" action, which was included in the Rural Development Program 2014-2020. The aim of this measure is innovative partnership and the formation of operational groups for innovation in the agricultural sector [17]. However, there is a large variation among Polish provinces, visible inter alia in the level of GDP (the level of GDP discussed in the article of the Warmian-Masurian Voivodeship constitutes $71.3 \%$ of the national average [6]), Therefore, it should be borne in mind that also the innovation indicator in the voivodship section will be very diverse.

\section{Theoretical Basis}

Poland's accession to the European Union had a significant impact on the improvement of Polish agriculture, for example due to the necessity to adjust Polish production to European standards. Technological or organizational development of Polish producers and entrepreneurs was necessary to remain on the market [3]. The changes affected everyone, albeit not uniformly. It is well known that rural areas are perceived as less innovative than urbanized areas [2]. The difference between cities and rural areas is not the only one. There is a high regional diversity in Poland in the level and dynamics of development resulting from a number of different aspects, including natural conditions such as the vegetation period, terrain configuration or soil diversification. These features make the agriculture of the Warmian-Masurian Voivodship require a high level of technical utilities and cause that unit costs of agricultural production are higher, while profitability is lower than in other regions of the country [14]. In this situation, innovation is an opportunity for the community of this region, as Schumpeter said, innovation is a chance for firms to pursue economic rent in the short-term [4]. The results of the Szwacka-Mokrzycka research show that the factors that have the strongest impact on the development of innovation in the agri-food sector (research in the Podlasie Voivodship - $0.4 \%$ of GDP less than in the region discussed in the article) is the help of EU funds or state support, i.e. use of external sources of financing [15] and also access to informations. Maciejczak also emphasizes that funds from the EU funds allowed to finance innovative investments in both medium and large farms [8,9]. Among innovations Kaluza and Ginter specify such categories:

- innovation in the field of plant production: new fertilizers and plant protection products, new crop species and varieties, new technologies, purchase of machinery and equipment, soil analysis, certified seed, increasing the area of arable land at the expense of permanent grassland;

- innovation in the field of livestock production: increasing the cattle and pig population, construction or modernization of livestock rooms, improvement of 
animal welfare, installations of new machinery and equipment, new species and breeds of animals, changes in animal nutrition;

- general farm innovations: purchase or lease of land, construction or reconstruction of premises farms, purchase of machinery, equipment and tractors, implementation of computer technology, new forms of work organization on the farm, searching for new sources of income [7].

There are many innovativeness classifications depending on the criterion adopted. Skornicki accepted the division into criteria: the form of innovation (tangible and intangible), the degree of innovation complexity (unconjugated and coupled), objective (product, process, marketing and organizational), the mechanism of stimulating innovation (supply and demand) [13]. However, regardless of the breakdown, the increase in innovation was identified in the RDP 2014-2020 as one of the main needs on the way to the development of Polish agriculture. Innovation can significantly affect the improvement of productivity and increase the competitiveness of the agricultural sector, as well as improve the quality of products, which in turn may contribute to increasing farmers' incomes [1]. At the same time, innovative solutions may be conducive to adaptation of agricultural activity to the needs of the environment $[11,12$, $16]$.

\section{$3 \quad$ Methodology}

The study analyzes the farmers' innovative activities in their farms. The aim of the research was to identify and evaluate the implementation of innovative solutions and their application in agricultural farms. Primary and secondary sources of information were used for analyzes. Empirical research on application and approach to innovation was conducted in the form of interviews in the third quarter of 2018 among thirty farm owners in the Warmian-Masurian Voivodeship. These studies constituted a farmer's approach to implementing innovations in their farms. $56 \%$ of respondents were women, and $44 \%$ were men. The vast majority, as many as $70 \%$ were people aged 46 to 59 . Respondents used land from 2 to 14 hectares. The study used the author's questionnaire. The results of the research were developed statistically and graphically. Secondary sources of information came from the subject literature and statistical studies of the European Commission.

\section{$4 \quad$ Results}

Farmers responded to the question about already realized an innovative venture (see Fig.1). Among the respondents only $20 \%$ have such an experience already made. In the case of planning the implementation of innovations (see Fig. 2), one more respondent answered that is going to run some innovative activity. Another $23 \%$ respondents answered that is hard to say. The respondents who answered so, were asked to define why it is "hard to say", what it depends on, answers were as follows: 
- it depends on the support of the community,

- it depends on whether there will be some EU funds,

- it depends on whether the state will give funds for it,

- it depends on health.

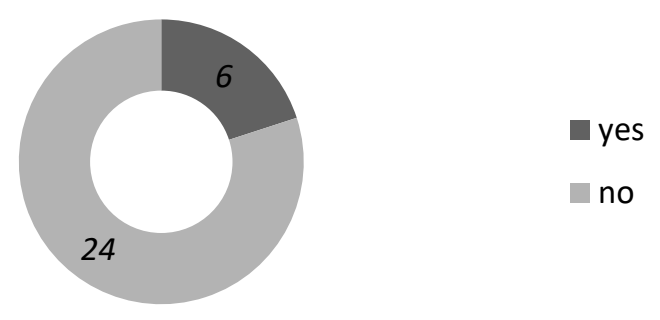

Fig. 1. The respondents who implemented innovations on the farm before the interview.

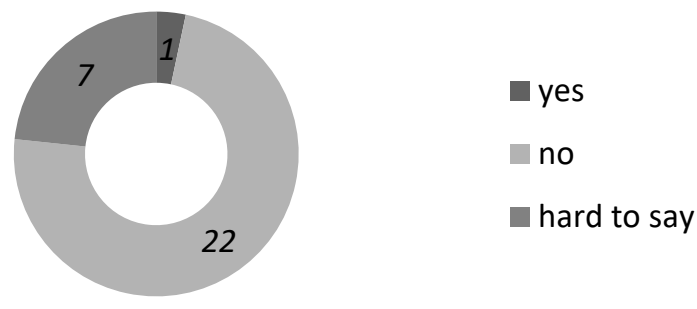

Fig. 2. The respondents who plan to implement innovations in their farm.

Among introduced or planned innovations in the surveyed farms there were: lease or purchase of land, renovation of buildings, construction of a lodging, purchase of a machine, creation of an additional source of income.

Respondents also answered the question about the possibilities of farming since Poland was included in the Rural Development Program (RDP). A large majority decided that opportunities for farming since Poland is included in RDP have been improved, whereas nobody decided that farming opportunities have been deteriorated (see Fig. 3). 


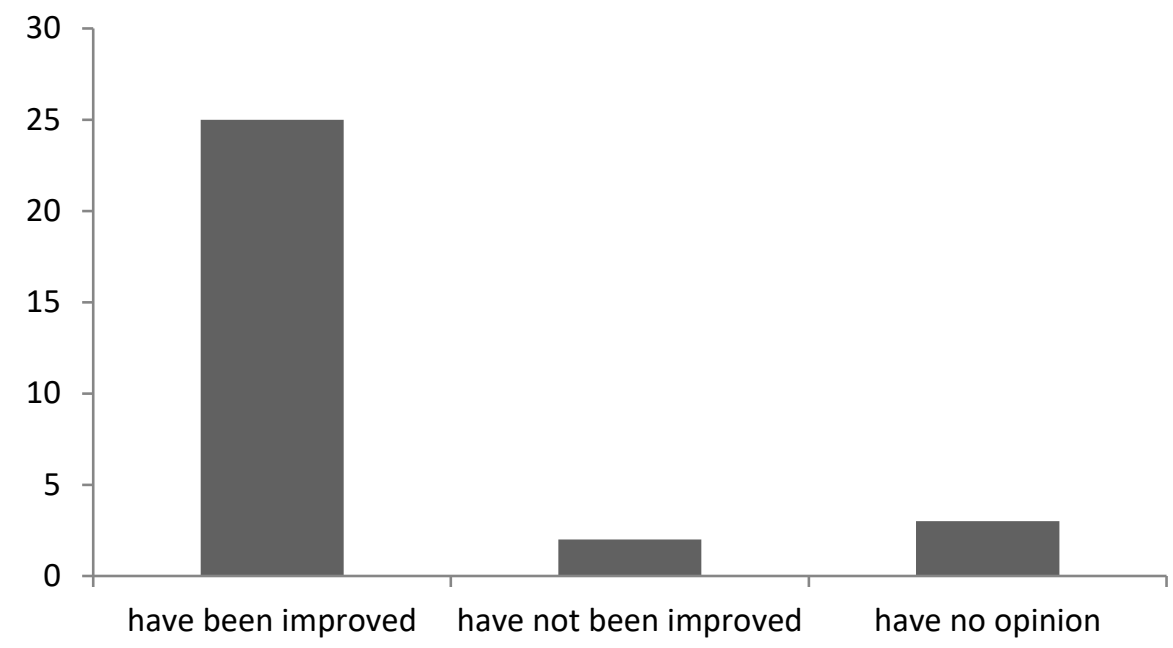

Fig. 3. Opinions of respondents regarding the opportunities for farming after including Poland the RDP program.

Also respondents were asked to indicate what types of innovations (in their opinions) are profitable to implement in the local area. Respondents defined profitability using a five-point scale. Each responder had to award two best options.

Table 1. The level of profitability of innovation in the opinion of respondents [in \%].

\begin{tabular}{lcc}
\hline Innovation type & The most common answer & Share [\%] \\
\hline $\begin{array}{l}\text { Innovations in the plant } \\
\text { production }\end{array}$ & 3 & 70 \\
\hline $\begin{array}{l}\text { Innovations in the livestock } \\
\text { production }\end{array}$ & 3 & 47 \\
\hline $\begin{array}{l}\text { Innovations for } \\
\text { expanding/improving the farm }\end{array}$ & 5 & 80 \\
\hline New sources of income & 4 & 53 \\
\hline New work organization & 2 & 47 \\
\hline New technology & 4 & 57 \\
\hline Others & 3 & 63 \\
\hline
\end{tabular}

The highest scores (5) were given to the answers of the expansion, farm enlargement, namely the general farm innovations. At the good grade (4), respondents also assessed the possibility of implementing a new source of income in their farms and also the possibility of start using new technology in their work. The new organization of work 
on the farm was poorly assessed (2) as unprofitable for the local conditions of the respondents. The "others" section contained such innovations as: soil analysis, certified / genetically modified seed and it has been assessed rather unfavorably (3).

The Warmian-Masurian residents were asked to indicate which of the proposed projects should be developed by the commune and poviat authorities. Each responder had to award two best projects. The authors proposed the following undertakings:

- facilitating knowledge transfer and innovation in agriculture and forestry in rural areas (3\%),

- improving the competitiveness of all types of farming and increasing the profitability of farms (35\%),

- improving the organization of the food chain and promoting risk management in agriculture (8\%),

- recreation, protection and strengthening of ecosystems dependent on agriculture and forestry $(3 \%)$

- supporting resource efficiency and the transition to a low-carbon and climate resilient economy in the agricultural, food and forestry sectors (5\%),

- increasing social inclusion, reducing poverty by promoting economic development in rural areas $(45 \%)$.

The most important undertakings that the commune and poviat authorities should have developed are for the respondents: increasing social inclusion, reducing poverty by promoting economic development in rural areas, that is, social aspects and help entrepreneurs in improving the competitiveness of the agricultural economy and increasing the profitability of farms, so the management issues.

Furthermore, respondents were asked about the their opinions why farmers from the region are not willing to implement innovations. The following are the most common answers:

- innovations are unprofitable,

- farmers do not have enough knowledge,

- farmers do not receive sufficient help from specialists in this field,

- farmers do not want to develop the farm more,

- farmers have no motivation,

- there are no young people on the farms,

- there is not enough financial encouragement from the state.

The figure 4 shows the number of indications given to the reasons for not implementing innovation. 

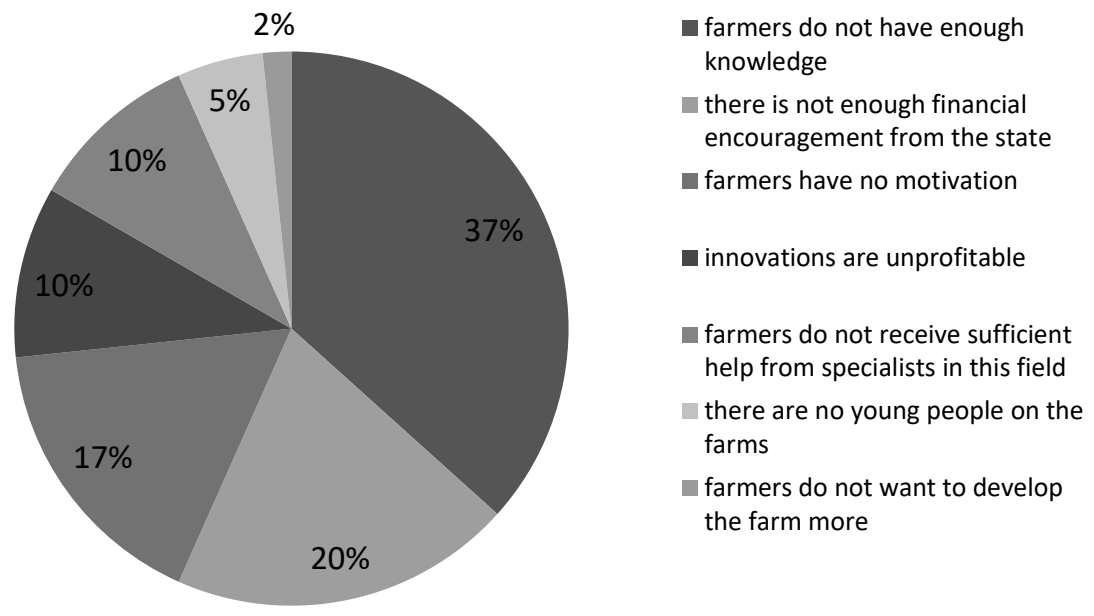

Fig. 4. Respondents indications why farm owners do not want to implement innovations [in \%].

It was examined that despite a significant stimulus to implement innovations which is the possibility of obtaining external funds, the lack of knowledge in the field of innovation was the main reason for the lack of innovation initiatives on farms. This is logical, because currently in the region, in Poland and in the European Union, there are projects, funds for innovations that would definitely help farmers to innovate, but to reach for them, farmers should have knowledge, an idea for innovation, but this knowledge is lacking.

\section{Conclusion}

According to analyzes of respondents' answers, the willingness to implement the innovation is largely restrains by a lack of innovations' field knowledge. Among the small percentage of people who implemented innovations, the most popular were general farms innovations: purchase of land, lease of land, construction / reconstruction of farm rooms, purchase of machinery and equipment or modernization of buildings. The majority of interviewed farmers stated that since the Polish was included in the RDP, the farming opportunities have been improved. However, what the commune and poviat authorities should pay special attention to are increasing social inclusion, reducing poverty by promoting economic development in rural areas and help with improving the competitiveness of all types of farming and increasing the profitability of farms. It is worth noting that both of these aspects can be taken care of by 
implementing innovations or assistance in implementation, for example by providing/transfer knowledge to local producers and entrepreneurs.

\section{References}

1. Brozek, K.: Comparative analysis of selected determinants of innovation in EU countries. In: Maresova, P. et al. (eds.), Proceedings of the 16th International Scientific Conference Hradec Economic Days, 8(1), pp. 129-139. University of Hradec Kralove in Hradec Kralove, Czech Republic (2018).

2. Galliano, D., Goncalves, A., Triboulet, P.: Eco-innovations in rural territories: organizational dynamics and resource mobilization in low destiny areas. Journal of Innovation Economics \& Management, 24(3), 35-62(2017). DOI: 10.3917/jie.pr1.0014

3. Gorynska-Goldmann, E., Gazdecki, M.: Buying factors as an innovation platform on regional and traditional products market. Annals of the Polish Association of Agriculture and Agribusiness Economists, 18(6), 35-41(2016). DOI: 10.1080/07421222.2018.1440768.

4. Ho, K., Nguyen, C., Adhikari, R., Miles, M., Bonney, L.: Exploring market orientation, innovation and financial performance in agricultural value chains in emerging economies. Journal of Innovation \& Knowledge 3(2018), 154-163 (2017). DOI: 10.1016/j.jik.2017.03.008.

5. Badania naukowe i innowacje - EUROPA,https://europa.eu/europeanunion/topics/research-innovation_pl, last accessed 2018/10/17

6. GUS: Wstępne szacunki produktu krajowego brutto według województw w 2016 r., https://stat.gov.pl/obszary-tematyczne/rachunki-narodowe/rachunki-regionalne/wstepneszacunki-produktu-krajowego-brutto-wedlug-wojewodztw-w-2016-r-,4,5.html last accessed 2018/10/27

7. Kaluza, H., Ginter, A.: Innovations in agricultural farms of young farmers (innowacje w gospodarstwach rolniczych mlodych rolnikow). Research Papers of Wroclaw University of Economics 361, 89-98 (2014).

8. Maciejczak, M.: New directions of innovation in the agricultural sector (Nowe kierunki wsparcia innowacyjności sektora rolnego). In: Baczko, T., Puchala Krzywina, E. (eds.) Raport o Innowacyjnosci Gospodarki Polski w 2012 roku., INE PAN, Warsaw (2013).

9. Maciejczak, M.: Innowacyjnosc sektora agrobiznesu. Uwarunkowania i perspektywy rozwoju. In: Baczko, T.(eds.) Raport o innowacyjnosci gospodarki Polski w 2011 r., INE PAN, Warsaw (2012).

10. Matras-Bolibok, A., Bolibok P.: Internal driving forces of collaboration on innovation activity. In: Proceedings of the 13th International Scientific Conference Hradec Economic Days, 5(4), pp. 356-362. Univeristy of Hradec Kralove in Hradec Kralove, Czech Republic (2015).

11. Olkiewicz, M.: Ecoinnovations as a strategic foresight effect. Annals of the Polish Association of Agriculture and Agribusiness Economists, 18(6), 152-156(2016). DOI: 10.1080/07421222.2018.1440768.

12. Sayer, J., Cassman K.: Agricultural innovation to protect the environment. In: Proceedings of the National Academy of Sciences of the United States of America, pp. 8345-8348. PNAS 21(110), (2013), DOI: 10.1073/pnas.1208054110.

13. Skornicki, H.: Introduction to innovation in agriculture (Wprowadzenie do innowacji w rolnictwie). https://docplayer.pl/28501115-Innowacje-w-rolnictwie-henryk-skornicki.html last accessed 2018/10/28 
14. Suchta, J., Jasinski, J.: Evaluation of economic, social and spatial development of the Warmian and Mazurian Voivodeship (Ocena rozwoju ekonomicznego, spolecznego i przestrzennego wojewodztwa warminsko-mazurskiego). Kwartalnik Naukowy, Nauki Spoleczne 4, 67-80 (2013).

15. Szwacka-Mokrzycka, J., Miara, A.: Assessement of the impact of selected factors on the development of innovation in the agri-food sector in the Podlaskie Voivodship. Annals of the Polish Association of Agriculture and Agribusiness Economists, 20(2), 151-156(2018).

16. Tabaka, A.: Innovations in agriculture and on rural areas (Innowacje w rolnictwie i na obszarach wiejskich). Warminsko-Mazurski Osrodek Doradztwa Rolniczego W Olsztynie, Olsztyn (2015)

17. Wiatrak, A.: Network of innovations in agriculture - essence, aims and conditions. Annals of the Polish Association of Agriculture and Agribusiness Economists, 18(3), 380-384 (2016). 